\title{
Crude Oil and Fractional Spillages Resulting from Exploration and Exploitation in Niger-Delta Region of Nigeria: A Review About the Environmental and Public Health Impact
}

\author{
John Kanayochukwu Nduka, Fabian Onyeka Obumselu \\ and Ngozi Lilian Umedum \\ Environmental Chemistry and Toxicological Research Unit, \\ Pure and Industrial Chemistry Department, \\ Nnamdi Azikiwe University, Awka, \\ Nigeria
}

\section{Introduction}

The Niger Delta basin of Nigeria situates on the continental margin of the Gulf of Guinea in the equatorial West Africa between latitudes $3^{\circ}$ and $6^{\circ}$ North and longitudes $5^{\circ}$ and $8^{\circ}$ East. The word "Delta" is derived from a Greek alphabet in shape of a pyramidal triangle. A delta is a geographical feature formed when a River diversifies into numerous streams that sometimes inter-connect into an intricate web of Rivers, lagoons, swamps and wet land. The point where the main rivers divides is the top of the pyramid while the base is where the division ends or the River enters the sea or larger water course such as a lake. The Niger Delta on the Atlantic coast is one of the moist important in the world. Other worlds notable Deltas include the Nile, Mississippi, Orinoco, Ganges and Mekong (Ibru, 2001). Deltas are usually fertile, contain diverse resources and are therefore noted for large human settlements and civilizations. The Niger Delta complex is one of the most prominent basins in West Africa and actually the largest delta in Africa. It includes the Imo River and Cross River deltas and extends into the continental margins of Cameroun and Equatorial Guinea (Reijers et al 1996).

A more rigorous scientific definition of the territory locates it between Aboh to the North, the Benin River to the west and the Imo River to the East. It is located in the Atlantic coast of Southern Nigeria where River Niger divides into numerous tributaries. The area is the second largest delta in the world spanning a coastline of about $450 \mathrm{kms}$ foreclosing at Imo River (Awosika, 1995). It is the largest wetland in Africa, spanning over 20,000 square kilometer and among the three (3) largest in the world. It is estimated that about 2,400sq.km of the area consist of rivers, creeks and estuaries while stagnant swamp covers about $8,600 \mathrm{sq} . \mathrm{km}$. Its mangrove swamp of 1,900sq.km is the largest in Africa (Awosika, 1995). The area falls within the tropical rain forest zone of Nigeria. The ecosystem is highly diverse and supportive of several species of terrestrial and aquatic flora, fauna and human life. It ranks 


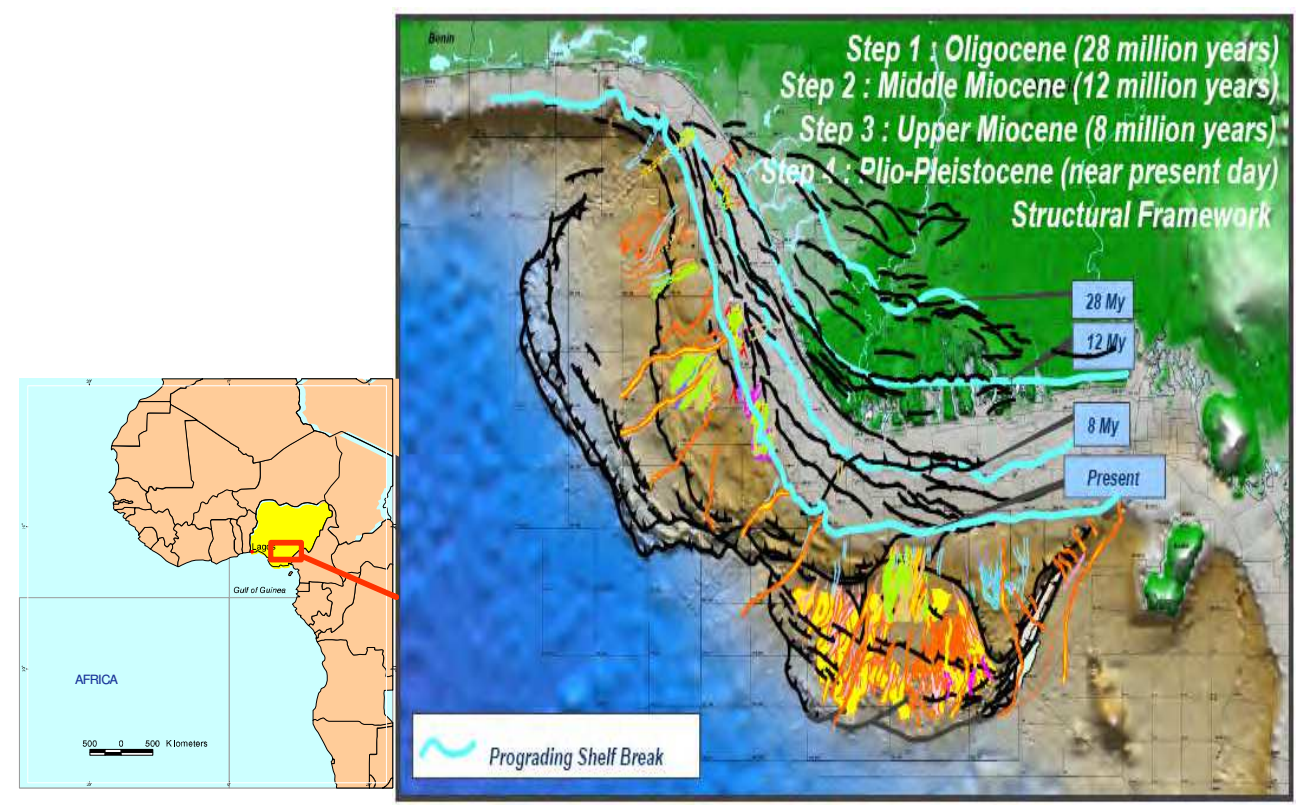

Fig. 1a. Location map of Niger Delta (Reijers et al, 1996).

amongst the world's most prolific petroleum tertiary delta that together accounts for about $5 \%$ of the world's oil and gas reserves and for about 2:55\% of the present day basin area on earth. Enormous petroleum reserves in the Niger Delta is estimated at about 30 billion barrels of oil and 260 trillion cubic feet of natural gas ranks the basin 6th in the world production (Reigers et al, 1996). The structural features and petrophysical properties account for the hydrocarbon occurrence. The region is divided into four zones namely coastal inland zone, mangrove swamp zone, fresh water zone and lowland rain forest zone. It has been reported that delta sediments are layered in structure, but layers of alternating sands, silts and clays may not be homogenous (Abam and Okagbue, 1997). Three (3) major formations exist in the area, namely Benin, Agbada and Akata. 


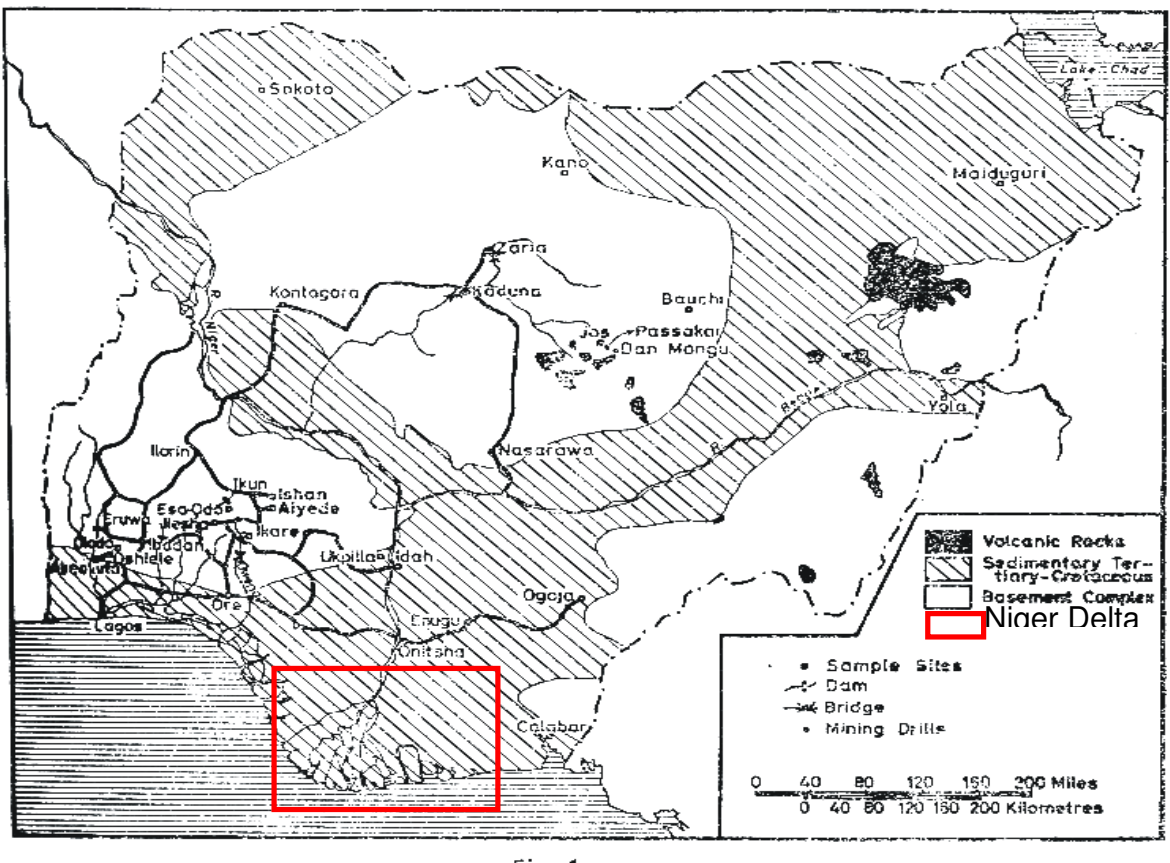

Fig. 1b. Location map of Niger Delta (Reijers et al 1996).

The Benin formation is mostly continental units of sand mixed with gravel and restricted clays, sequence of sandstone/shale exist in Agbada formation, which is the oil-reservoir in the Niger Delta basin (i.e. oil and gas in the area mainly occur in sandstone reservoirs throughout the Agbada formation). The Akata formation is regarded as over pressured shale (Lambert-Alklionbare et al, 1990). The soil of the area is mostly made up of Entisols and inceptisols, with traces of Alfisols (Ekundayo and Obuekwe, 2001). The dominant fresh water aquifer is found in the Benin formation, though there is shallow aquifer, the thickness of Benin formation generally exceeds $2000 \mathrm{~m}$ with high consolidation at deep levels (Amadi and Amadi, 1990). Accessible fresh water could occur in the first $100-200 \mathrm{~m}$ (Oteze 1983). Water levels can be located at less than $1 \mathrm{~m}$ near the coast to more than $10 \mathrm{~m}$ further inland (Amadi, 1986). The whole of delta region receives more than $5000 \mathrm{~mm}$ of rainfall annually (National Atlas, 1987). Evapo-transpiration is estimated at over $1000 \mathrm{~mm}$ per year, so there is adequate rainfall to recharge surface and ground water system, although organic matter and clay matrix that consolidate the soil may interfere with infiltration and seapage into the aquifer (Ekundayo and Obuekwe, 2001). The rapid urbanization and industrialization of the Niger delta region of Nigeria occasioned by huge crude oil and gas reserves has had its tole on the environment. Being the most naturally endowed by housing the oil and gas reserves that derive the nation's economy to the vast network of interwoven freshwater aquifers, extensive low lands, tropical and fresh water forest and aquatic ecosystems to its biodiversity with temperature, sunlight and rainfall in an amount and combination that support cultivation and bountiful harvest of rice, sugar cane, yams, plantains, cassava, oil palm, rubber and timber (Nduka et al, 2008). The exploitation of the huge reserve of crude 
oil and gas deposits has resulted in several million barrels of crude and fractional spillages and several billion cubic feet of gas flaring leading to environmental damage. The US Department of Energy estimates that since 1960, there have been more than four thousand $(4,000)$ oil spills, discharging several million barrels of crude oil into the ponds, ditches, creeks, beaches, streams and rivers of the Niger Delta (Amaize, 2007).

\section{Composition of crude oil}

Crude or petroleum based oil refers to a wide range of natural hydrocarbon substances and refined products, each having a different chemical composition. Crude oil is a mixture of highly variable proportion of hydrocarbon but differs from lighter oils to heavier oils and bitumen. It is believed to have been formed several million years ago from decayed remains of animals and plants. Under the effects of heat and pressure, there is breaking down of decayed matter into liquids and gases, both collect into pools under the earth's surface. Definite molecular composition varies widely from formation to formation but the proportion of chemical elements differs little (Speight, 1979). Crude oil is the basic mineral product obtained from the geological strata. Though it is referred to as a single (uniform) mineral substance, in reality crude oil is a complex mixture of thousands of hydrocarbons and non hydrocarbons compounds. Of these, the hydrocarbons (Neumann et al, 1981) are by far the major components linked together with inter atom bonds, these hydrocarbons form a variety of kinds of molecules of many different shapes and sizes. Although crude oil are mixtures of some compounds, but the quantity of individual components vary widely in crude oils from different locations. The physical characteristics of oil, such as density, viscosity, flash point, pour point etc are determined by the characteristics of individual component and their relative quantities within the petroleum specific gravity determines whether a crude oil is classified as light or heavy (Wilson and LeBlanc, 1999/2000).

\begin{tabular}{|l|l|}
\hline Elements & \% Range \\
\hline Carbon & 83 to 87 \\
\hline Hydrogen & 10 to 14 \\
\hline Nitrogen & 0.1 to 2 \\
\hline Oxygen & 0,1 to 1.5 \\
\hline Sulfur & 0.5 to 6 \\
\hline
\end{tabular}

Table 1. Major Composition of crude Oil.

\subsection{Other constituents of crude oil}

2.1.1 Polycyclic aromatic hydrocarbons (PAHs): PAHs is a group of about 100 chemicals that are formed during the incomplete burning of coal, oil, gas, garbage, tobacco and other organic substances. They are also present in crude oil, plastics and pesticides (ATSDR, 1995).

2.1.2 Volatile organic compounds (VOCs): The most common volatile organic compounds in crude oil are the benzene, toluene, ethylbenzene and xylene. They are also mainly found in household products (paints, paint strippers, solvents, aerosol). 
2.1.3 Hydrogen sulphide gas: Some crude oils release high concentrations of hydrogen sulphide gas.

2.1.4 Alkanes (paraffin) and cycloalkanes: These are major constituents of crude oil, lower fractions are volatile at ordinary temperature.

2.1.5 Naturally occurring radon materials (NORM): the occurrence of natural radioactivity in oil and gas fields is well recognized worldwide and has been reported in Nigeria's Niger Delta (Jibiri and Emelue 2008). This radioactivity can result from the occurrence in both rocks and specific ores, of isotopes from the uranium and thorium decay series, normally with alpha and gamma radiation activity (Hamlat et al, 2001).

2.1.6 Metals and heavy metals. Crude oil contains trace metals present as minor constituents. More than sixty metals have been established to be in crude oils with Vanadium (V) and Nickel (Ni) as the most abundant (Tiratsoo, 1973). Metal components of crude oil occur as metalloporphyrin chelates, transition metal complexes, organometallic compounds, carbonylacids salts of polar functional groups and colloidal minerals (William and Robert, 1967, Lewis and Sani, 1981). Metal components of crude oil constitute serious problem to petroleum refining by causing corrosion or poisoning the cracking catalysts which reduces efficiency (Tiratsoo, 1973; William and Robert, 1967; Lewis and Sani, 1981). Trace metals such as arsenic (AS) decreases hydrogenation and isomerisation activity of catalysts, acting as permanent poison (Hettinger et al, 1955). Gas and coke formation in crack stock is enhanced by copper $(\mathrm{Cu})$ which promotes low gasoline production. Iron ( $\mathrm{fe}$ ) poisons catalysts and accelerates oxidation, which may result in unstable products (Milner, 1963, Ming and Bott 1956, Karchmer and Gunn 1952), Nickel deposits contaminate cracking catalysts more than any common metal leading to low gasoline yield. Vanadium during cracking processes is oxidized, yielding low melting pentoxide which deposits readily and contributes to catalyst poisoning, metal embrittlement and pitting of refining equipment and combustion deposits ash known to be toxic. Sodium ( $\mathrm{Na}$ ) on its own causes loss in catalytic activity, it also imparts corrosive properties and thereby reduces the life of furnace tubes, turbine blade and metal wearing (Karchmer and Gunn, 1952; Kawchan 1955; Bowman and Wills, 1967 and Garner et al., 1953). Presence of certain trace metals particularly nickel and vanadium in crude oils is geochemically significant and provides information on the origin of crude oil. The work of Achi and Shide, 2004 revealed that Nigerian Bonny light crude and Bonny medium crude contains varying quantities of calcium, magnesium, zinc, iron, nickel, sodium and potassium in the following order: $\mathrm{Na}>\mathrm{Ca}>\mathrm{Fe}>\mathrm{Ni}>\mathrm{Mg}>>\mathrm{K}>\mathrm{Zn}$ in Bonny light crude while Bonny medium crude is of the order: $\mathrm{Na}>\mathrm{Ca}>\mathrm{Fe}>\mathrm{Ni}>\mathrm{Mg}>>\mathrm{K}$ $>$ Zn. Sundry constituents of crude oils or those that may be synergized by certain or natural processes include nitrate, nitrite, polychlorinated-n-alkanes, polychlorinated biphenyls and several others.

\section{Activities involved in oil extraction}

\subsection{Exploration/drilling operations}

This include drilling and work over activities which takes place on land, swamp and offshore. Oil spill during drilling results from blow outs, equipment failure, waste pits, overflow and sometimes human error. 


\subsection{Production operations}

Production facilities include producing wells, flow stations, gas plants, compressors station, gas and water injection stations and numerous pipelines that connect these facilities. In production operations there are several potential sources of spill which ranges from equipment failure, valve and seals failure, operational errors and sabotage. Sometimes oil/chemical spills can be due to corrosion.

\subsection{Terminal operations}

This involves the filling of tanks, barges, vessels, dehydration of crude, crude storage, effluent water disposal and loading of tankers. Crude oil/fractional distillates spill can be due to hose and valve failure, tanker collision and grounding, ship to ship transfer, improper drainage of tanks, storage tank and pipeline failure.

\subsection{Engineering operations}

This include dredging, flow line replacement, flow station upgrade etc.

\subsection{Sabotage/theft}

It involves vandalization of manifold, pipelines delivery lines, cutting or removal of pipelines.

\subsection{Others}

Include falling trees, lightning and mystery (unexplainable) spills.

\section{Classification of oil spill}

Crude oil/chemical spills are classified according to a combination of factors notably real or potential impact on environment and the resources required for effective response. The Department of Petroleum Resources (DPR) has classified the magnitude of oil spillage into minor, medium and major spills.

\subsection{Minor spills}

The spills that are less than 25 barrels of crude oil discharged on inland water or less than 250 barrels discharged on land, coastal/offshore water.

\subsection{Medium spill}

This releases between 25 - 250 barrels on inland water or 250 - 2500 barrels discharged on land, coastal/offshore water.

\subsection{Major spill}

It releases greater than 250 barrels discharged on inland water or greater than 2,500 barrels discharged on land, coastal/offshore waters. 


\section{Fate and behavior of spilled oil}

When oil is spilled, over a period it undergoes a number of physical and chemical changes which affect its behavior. These changes start from the spread and drift of the oil through its evaporation, dissolution, dispersion and emulsification to its sedimentation, photooxidation and biodegradation. Biotic factors, like bacteria, yeast and filamentous fungi play an important role in the degradation of petroleum and may be the dominant factor controlling the fate of petroleum hydrocarbons in marine environment (Delaune et al, 1990).

\subsection{Spreading}

The spreading rate of oil will be affected by its viscosity, pour point, wax content, marine state and weather conditions. Slicks formed will move in the same direction and in the same speed as the current and will move in the same direction as the wind at approximately $3 \%$ of the wind speed. Less viscous oil spread faster than heavy oils (Clark, 1992), but all oils spread faster on warmer waters. Spreading also induces a change in the composition of the oil by promoting the dissolution and evaporation of certain components, also as hydrocarbon dissolves in water, they alter the water-air interfacial tension (National Research Council, 1985). The force of gravity acting downwards through the thickness of a considerable oil spill tends to spread it out sideways. This movement compares with that of oil on solid surface but limited when the viscosity of the oil counter balances the spreading force. When compared with effect of surface tension, this force becomes operational if there is a difference between the oil/air and oil/water interface tension, while it remains positive, the oil will spread out. Fay (1969), gave a theoretical treatment of the spreading of oils into three (3) separate phases.

- Where the spreading rate is controlled by the difference in density between the oil and the water and the speed of spreading controlled by inertia resistance.

- Where spreading rate is controlled by gravity but viscous drag between the oil and water limits the spreading rate.

- When the spreading is controlled by the surface tension difference between the oil and the water.

Here we consider the third or surface tension type, earlier work on this by Blokker (1964) considered the dynamics of the spreading and proposed an empirical formula based on the assumption that oil spreads in a uniform way where the instantaneous rate of spreading is proportional to the slick thickness.

Blokker's formula thus simplified:

$$
D^{3}-D_{o}^{3}=\frac{24 k}{2}(d w-d o) \frac{d o}{d w} V_{o} \cdot t \cdot g^{2}
$$

where;

$\mathrm{K}=$ Blokker's constant (depending on oil type)

$\mathrm{D}=$ Diameter of the oil spread in meters

$\mathrm{t}=$ time

do $=\mathrm{D}$ at time $(\mathrm{t}=\mathrm{o})$

do $=$ density of oil 
$\mathrm{dw}=$ density of water

$\mathrm{Vo}=$ initial volume of oil

An extensive experiment on spreading of oil and its disappearance was carried out by Warren Spring laboratory in 1972 and was described by Jeffrey (1973), here 120 tons of light Arabian crude oil was discharged at sea and its appearance and dimension studied for four (4) days on a uniform water surface, as might be found on the open sea, oil spread evenly in all directions but it is not practicable because of effect of wind and waves.

\subsection{Evaporation}

In evaporation, the rate and extent of evaporation is determined primarily by the volatility of oil, spreading rate, marine and wind conditions and temperature. Evaporation can be responsible for the loss of up to $40 \%$ spilled oil in the first day (Jordan and Payne, 1980). The amount of evaporation differs from about $10 \%$ in very heavy crude and refined product to as much as $75 \%$ in very light crude and refined products (Albers, 1995). From the study of the fate of oil in the Amoco Cadiz spill in 1978, off Brittany, France, it was established that lower molecular weight alkanes and single-ringed aromatics (benzenes) were rapidly depleted through evaporation (Gundlach et al, 1983).

\subsection{Dissolution}

The extent of dissolution is influenced by the oils aqueous solubility which for crude oil is put at 30mg/L (National Research Council, 1985). Low molecular weight aromatics such as benzene, toluene and xylenes which are also among the most volatile has the highest solubility. Actual dissolution of the slick would be expected to account for only around 1\% of the mass balance (Mackay and McAuliffe, 1989).

\subsection{Dispersion}

Oil-in-water emulsion or dispersion is due to the incorporation of small globules of oil into the water column. Dispersions are considered beneficial because they increasingly disperse over time and dramatically increase the surface area of the oil available for degradation (Jordan and Payne, 1980). These emulsions are inherently unstable and larger particles tend to rise and coalesce but small droplets can be conveyed with water eddies to become a part of the water column. Oil-in-water dispersions can also be stabilized by suspended particulates (Huang and Elliot, 1987).

\subsection{Emulsification}

Low viscosity oils tend to form emulsion very quickly ( 2 to 3 hours) and can be up to $80 \%$ content. Oils that have asphaltenes content, $70.5 \%$ are likely to form stable emulsion. These emulsions are problematic because they slow microbial degradation and are resistant to dispersion (Payne and Philips, 1985).

\subsection{Sedimentation}

Sedimentation of oil is facilitated by the sorption of hydrocarbons to particulate matter suspended in the water column. Since coastal environment of the Niger Delta contains large 
amount of suspended particulate matter (Nduka and Orisakwe, 2011), adsorption of oil onto suspended particulate matter results in a high specific gravity mixture more than twice that of sea water alone $\left(1.025 \mathrm{~g} / \mathrm{cm}^{3}\right)$. The high specific gravity of these particles causes deposition of the sorbed oil (Kennish, 1997). Increasing density of oil due to weathering can also promote its movement below the surface into the water column and eventually into sediments (National Research Council, 1985).

\subsection{Photo-oxidation}

UV radiation has enough energy to transform many petroleum hydrocarbons into compounds possessing significant chemical and biological activity (Jordan and Payne, 1980). The mechanism is known as auto catalytic free-radical chain reaction, which results in the formation of hydroxyl compounds, aldehydes, ketones and low molecular weight carboxylic acids (Burrwood and Speers, 1974, Jordan and Payne, 1980). Photo-oxidation of hydrocarbons derived from crude oil can occur from evaporated components in the gaseous state (Baek et al, 1991), from the dissolved fraction of petroleum (Neff, 1985) and from non dissolved oil like slicks and colloidally dispersed oil (Jordan an Payne, 1980). Organosulphur compounds reduce complete oxidation to carboxylic acids by leading to termination of free radical chain reaction (Jordan and Payne, 1980). Photo-oxidation rates can be increased by the presence of photo-sensitizing compounds such as xanthone-1-naphthol and other naphthalene derivatives and by the effect of dissolved ions of variable oxidation state such as vanadium that acts as catalysts (Jordan and Payne, 1980). Obviously, throughout the life of an oil slick, it continues to drift on the sea surface. The wind induced effect is normally taken as $3 \%$ of the wind velocity and the current effect is taken as $100 \%$ of the current velocity.

\subsection{Time scale for different process in weathering}

Time scale for different process in weathering

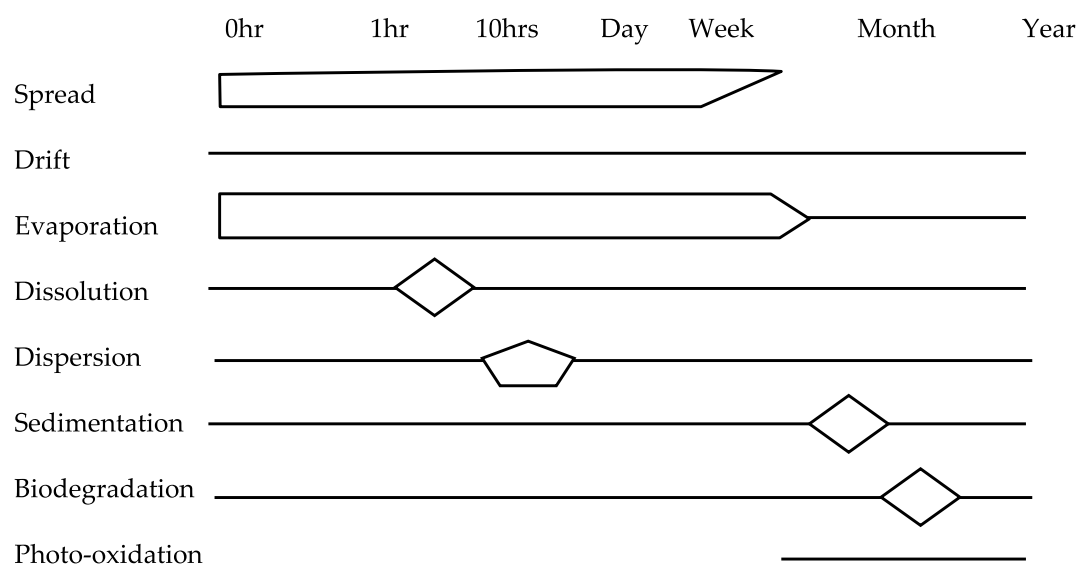

Scheme 1. 


\subsection{Micro-bial degradation}

Micro-organism indigenous to soil, groundwater and marine ecosystems degrade a wide range of compounds like aromatic and aliphatic hydrocarbons, chlorinated solvents and pesticides released into natural environment (BICNEWS, 2005). Since empirical evidence that aromatic hydrocarbons exist in the Niger Delta marine ecosystem due to extensive crude oil and gas exploitation, fire explosions, leachlets from decomposing refuse and industrial effluents (Okoro and Ikolo, 2005; Anyakora et al 2004; Anyakora and Coker 2006; Olajire et al, 2005), native microbes could be assisting Nigerians in the Niger Delta region in cleaning water system unnoticeable and free of charge. From our work (Nduka and Orisakwe, 2011), fewer or no counts of achromobacter and aspergillus (polyaromatic hydrocarbon (PAHs) degraders) and proteus (straight chain hydrocarbon degraders) were found in most water samples while bacillus and pseudomonas, both PAHs and straight chain hydrocarbon degraders (Rosenberg, 1993), were found in highest counts and in almost all the water samples. It was evident that water samples in which PAHs and straight chain hydrocarbon were highest, had highest microbial count per specie (figs 2a, 2b, 2c and Tables 2 and 3) (Nduka and Orisakwe, 2011). Therefore the low levels or non detection of PAHs and straight chain hydrocarbons could mean degradation by microbes (utilization of carbon as food by microbes for sustenance). This observation agrees with previous report (Atlas 1991, Young and Cerninglia 1995).

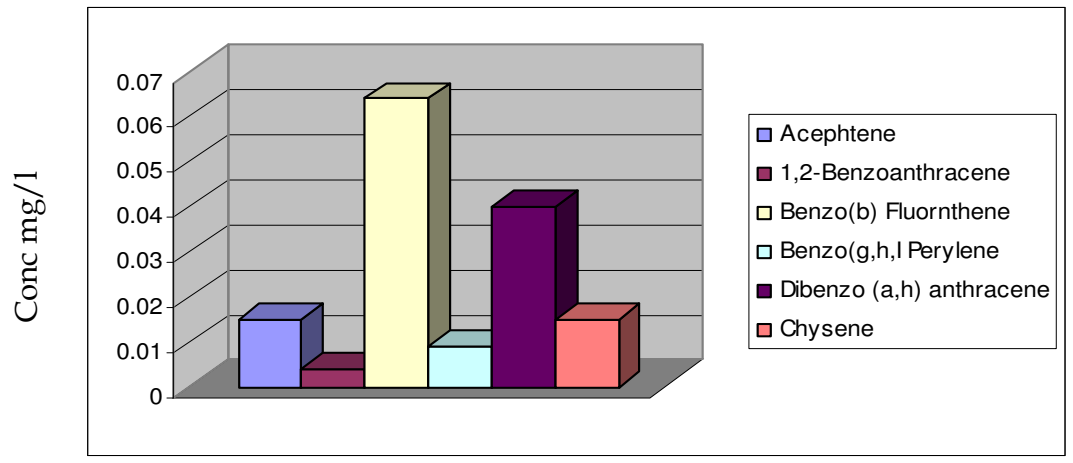

Fig. 2a. Some PAHs (mg/l) in water sample from Anieze river in River State.

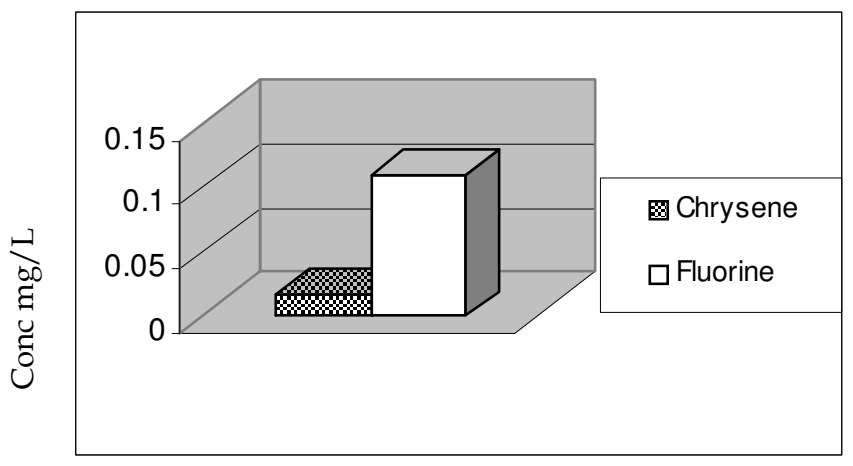

Fig. 2b. Some PAHs (mg/l) in water sample from Orashi River in Rivers State. 


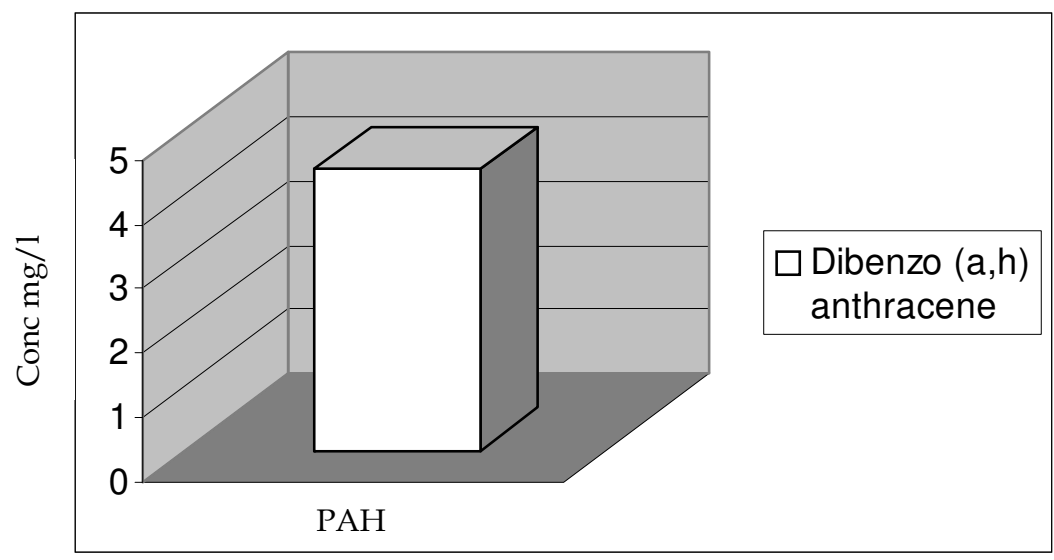

Fig. 2c. Dibenzo (a,h) anthracene $(\mathrm{mg} / \mathrm{l})$ in water sample from Ifie-Kporo River in Delta State (Nduka and Orisakwe, 2011).

Heavy and complex compounds are more resistant to microbial degradation, but many are degradable by micro organism to a large extent. Some of the heavy and more complex compounds will eventually settle to the marine floor (Neilson, 1994). Put together, 40 to $80 \%$ of crude oil can be degraded due to microbial action (Albers, 1995). The most significant factors that affect crude oil (hydrocarbon) degradation by microbes include microbe type, water temperature, nutrient availability, amount of oxygen, salinity and bioavaible surface of the oil (Atlas and Bartha, 1973, Kennish, 1997). Microbial degradation is inhibited by mouse formation (which reduces the surface area of the oil available to biodegradation) and by cool water temperatures (Galt et al, 1991). Anaerobic conditions severely restrict microbial degradation (Gundlach et al, 1983). Oil deposited in the bottom sediments of sheltered estuaries and wetlands can persist for more than ten(10) years (Teal, 1993).

\section{Crude oil toxicity}

Toxicity of crude oil largely depends on the concentration of oil in water, dispersed into the water at low concentration $(<1 \mathrm{ppm})$, it is very little problem and will quickly get broken down. At higher concentration, it is toxic to most life forms and floating on the surface of water, it will physically smoother on everything it touches. The majority of most types of oil will float on water surface when spilled, but some will dissolve into water and with the help of wave action, some will be dispersed into small droplets. The most likely impact of oil floating in the sea is on the sea birds. Any oil sinking down into the water, both dissolved and dispersed could affect marine life particularly if the water is shallow and the oil toxic.

It is unusual, however for significant concentration of oil to go deeper than 5 metres below the surface, so there is not usually great concern for marine life below this depth. (SPDC, Nigeria, 1997). 


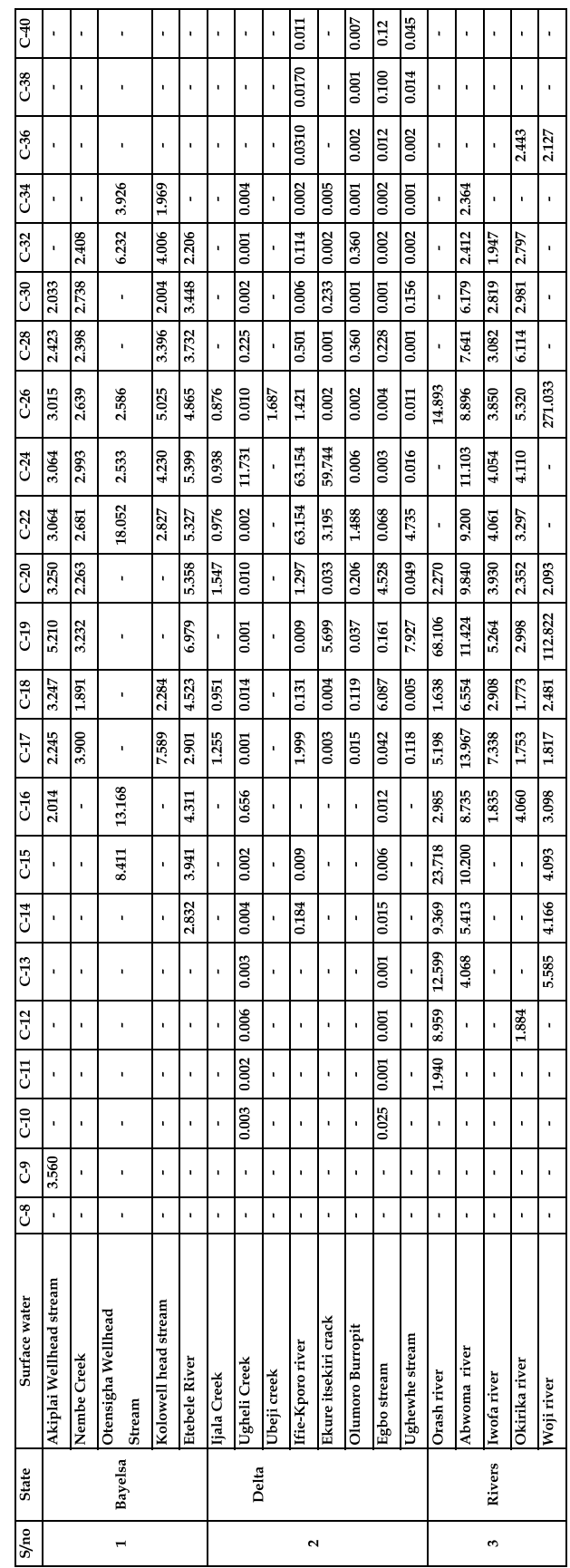

Table 2. Concentration (Mg/L) Of Straight Chain Aliphatic Hydrocarbon In Some Selected Surface Water Of Niger Delta (Nduka and Orisakwe, 2011). 


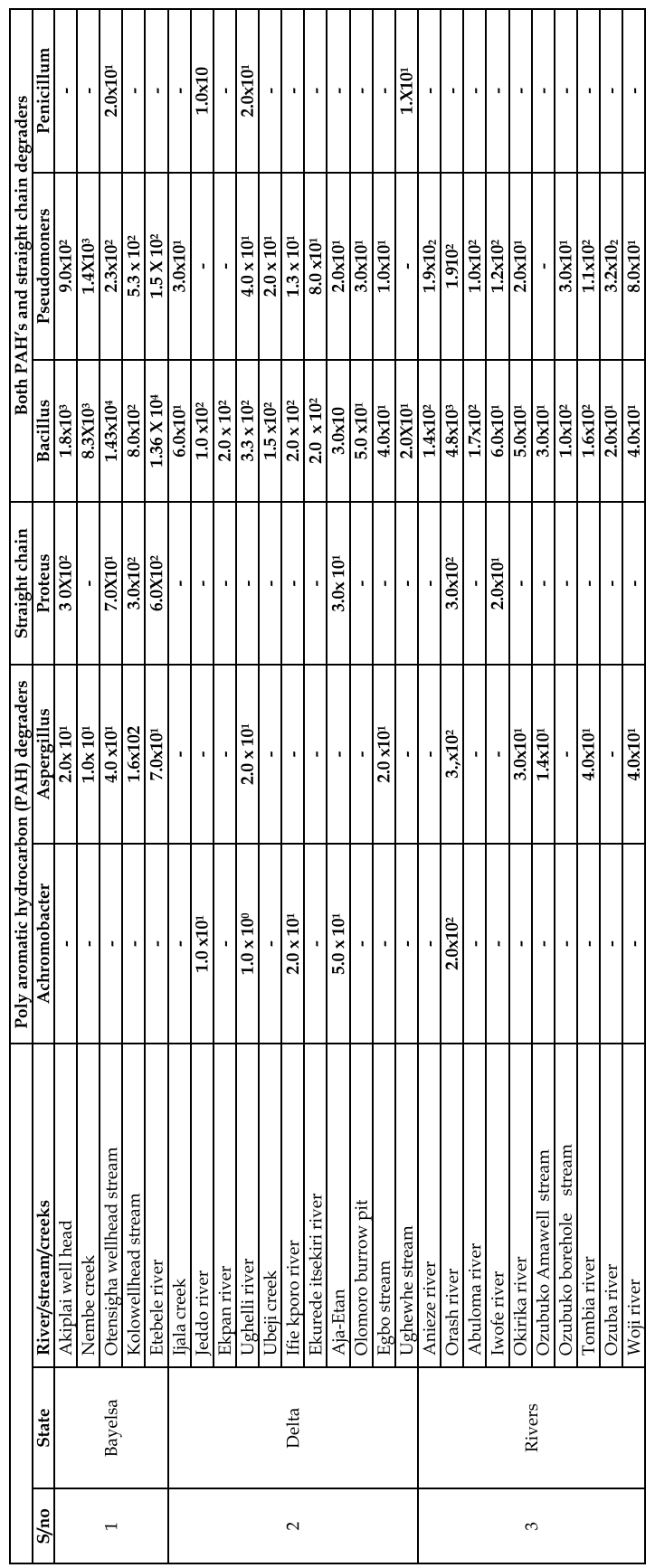

Table 3. Amount (Mg/L) Of Bacterial Count In Selected Water Samples Of Niger Delta (Nduka and Orisakwe, 2011)Impact of Crude Oil Spill on the water organism. 


\subsection{Planktons}

Planktons are the basis of marine food chain and it includes eggs and larvae of fish and other animals. It is very sensitive to the toxicity of oil and lots of planktonic organism will be killed, particularly if the concentration of oil in the water is increased by the wave action or chemical dispersants, therefore it is possible in a worst case scenario for the effect on the plankton to lead to some longer term effect (Adeyemi, 2004).

\subsection{Aqua culture}

Fish in fish farms are trapped by the nets and cannot escape the oil while it is quite likely that the fish may not die since they are tolerant to oil; they will be likely tainted. Tainting is where the fish absorbs oil from the water and its flesh when eaten tastes off, if the tainting is severe which is most likely to happen if a lot of oil has been dispersed into the water, the fish may be indelible leading to economic loss (SPDC Nigeria 1997, Adeyemi, 2004).

\subsection{Fish}

Adult fish have very sensitive sense organs so they taste the oil and quickly leave the area of the spill, unless they are trapped there in some way. It is very rare to have large fish kills due to marine oil spills. Juvenile fish however are more vulnerable since they often live in shallow water near shore areas known as "nursery areas" until they become adult. If a toxic oil impact a shallow bay and the oil is dispersed down into the water, the increased concentrations could have severe effects on juveniles and will result in long term impacts on adult fish stocks. This been evidenced in the Niger-delta region of Nigeria. Polyaromatic hydrocarbon (a carcinogen), been lipophylic tend to accumulate more in fish than in the sediment and least in the water samples of the region. Fish therefore is the best biomarker for the levels of PAHs contamination in marine samples (Anyakora et al, 2005). Nitrate pollution which has been reported in the area (Nduka and Orisakwe, 2011), at increased concentrations are harmful to aquatic animals. Marine invertebrates and fish exposed to nitrate may be smaller in size, have reduced maturity rate and lower reproductive success. In extreme high exposure levels, aquatic invertebrates and fish may die (Ohio State University, 2008). Early life stages of aquatic animals are more sensitive to nitrate than juvenile and adult animals. Early studies by Gbadebo et al, 2009, showed that petroleum oil, whether crude oil or spent oil is very toxic to fish (Clarias garipinus fingerlings), but spent oil produced more toxic effects on the clarias fingerlings at every concentration than that of crude oil. Their findings is supported by the fact that the water-soluble components of crude oil are toxic and could affect the survival and metabolism of aquatic animals like fish (Cote, 1976).

\subsection{Sea birds}

Sea birds are very easily affected by oil on the surface water because they spend long period sitting on the water. The oil is soaked up by their feathers and cannot fly, feed or preen themselves. They ingest oil which then damages their gut, die of starvation, cold, poisoning or shock. The sensitivity of species of birds to presence of oil vary. The impact on local population of birds can be serious and result in reduced population for many years (SPDC, Nigeria, 1997). In their work, Fry et al, 1986, showed that when wedge-tailed shearwaters 
birds were exposed to weathered Santa Barbara crude oil, it resulted in a greatly reduced number of eggs laid and complete hatching failure of 60 pair of exposed birds. Oral doses of oil in gelatin capsules reduced laying and breeding success but to a lesser extent than external exposure, also survival of chicks of dosed birds were reduced. It has also been observed that exposure of birds to crude oil before breeding delayed sexual maturation or onset of lay of eggs in captive mallards (Holmes et al, 1978, Coon and Dieter, 1981). Some crude oils are embryotoxic and if ingested during the period of egg formation may affect the development of progeny (Gorsline and Holmes, 1982b).

\subsection{Dispersant problem}

To stem the effect of oil spill, different grade of chemicals (dispersants) were developed to dispose the oil and subsequently hasten its sinking. The use of dispersants to deal with oil spills should be seen as an aid to the process of natural dispersion. Dispersants reduce surface tension of oil/water interface thereby breaking the oil slick into fine droplets that are then dispersed into the water column, for each dispersant, there will be a different range of effectiveness. The range of effectiveness is related to the concentration of the emulsifiers in the formulation, the effectiveness of the emulsifiers and the type of solvent used.

One of the disadvantages of dispersants is that they introduce a second source of pollution into the marine environment and indeed most of the opposition to their use stems from this fact. If a dispersant works effectively, then it is removing the oil from the water surface and distributing it throughout the body of the water. The upper section (normally top 3 metres) of the water column will contain fairly high concentrations of oil and this may reach toxic levels (SPDC, Nigeria 1997).

\section{Chemical pollution associated with oil spill}

Apart from environmental devastation associated with oil spill, the chemical constituents of the spilled oil induce toxic effect to the plant, animals, man and aquatic organism. Polyaromatic hydrocarbon (PAHs) are a class of compounds composed of two or more aromatic rings. They are a component of crude and refined petroleum products. Petroleum production, import and export of petroleum products also contribute a lot to the extent of PAH contamination especially in the marine samples (Baek et al 1991, Lorber et al 1994, Nwachukwu 2000, Nwachukwu et al 2001). They have been reported in water samples, fish species and soil sediments of the Niger Delta region of Nigeria which has had extensive petroleum production activities over the past few decades (Anyakora et al 2005, Anyakora and Coker 2006, Anyakora et al 2005). PAHs are classified as environmentally hazardous organic compounds due to their known or suspected carcinogenicity and are included in the European community (EC) and United States Environmental Protection Agency (USEPA) priority pollutant list (Nieva-Cano et al, 2001). These, with metals, volatile organic compounds (VOCs), and others have been previously discussed under composition of crude oil.

\section{Air pollution resulting from crude oil refining and gas flaring}

Crude oil exploration in the Niger delta region Nigeria has resulted in gas flaring, fire and gas explosions and bush burning, results in air borne particulate matter, also called 
suspended particulate matter (SPM) can be found in ambient air in the form of dust, smoke or other aerosols. SPM can occur as a secondary aerosol resulting from atmospheric transformation of gaseous pollutants emitted from combustion sources such as power plants and automobiles or natural sources such as forests. Particles can also result from condensation of volatile elements and species in the atmosphere and form very small particles or absorbed on the surface of already formed, finely divided particles. The combustion of crude oil associated gas (flaring) releases several gases into the atmosphere. Carbon monoxide (CO) is emitted into the atmosphere mainly as a product of the gas, it is accompanied by release of carbon (iv) oxide $\left(\mathrm{CO}_{2}\right)$ (a green house gas) (Ideriah and Stanley, 2008). Average value of $69.25 \mu \mathrm{gm}^{-3}$ of $\mathrm{CO}_{\mathrm{z}}$ level have been reported in Niger-delta. Release of $\mathrm{CO}_{2}$ has potential to adversely affect the health and well-being of nearby organisms (Nwaichi and Uzazobona 2011). Hydrogen sulphide is also present in air as a result of gas flaring, although Nigerian crude oil is reputed to have few milligram per litre of sulphur. $\mathrm{H}_{2} \mathrm{~S}$ can also result from microbial decay of organic matter and sulphate ion reduction

$$
\mathrm{SO}_{4}{ }^{2-}+2\left(\mathrm{CH}_{2} \mathrm{O}\right)+2 \mathrm{H}^{+}---------\rightarrow \mathrm{H}_{2} \mathrm{~S}+\mathrm{H}_{2} \mathrm{O}+2 \mathrm{CO}
$$

Sea water as found in the Niger delta region has high sulphate ion, bacterially induced formation of $\mathrm{H}_{2} \mathrm{~S}$ causes pollution problems in coastal regions as in our study area and is a major source of atmospheric sulphur (Manahan, 1979). Oxides of nitrogen ( $\mathrm{N} 0_{\mathrm{x}}$ ) and ammonia can also result from crude oil associated gas flaring and refining operations Ammonia in polluted atmosphere reacts readily with acidic materials. Such as sulphuric acid aerosol droplets to form ammonium salts (Ideriah and Stanley, 2008).

$$
\mathrm{NH}_{3}+\mathrm{H}_{2} \mathrm{SO}_{4}
$$

Oxides of sulphur $\left(\mathrm{SO}_{\mathrm{x}}\right)$ and that of nitrogen $\left(\mathrm{NO}_{\mathrm{x}}\right)$ primarily affect the respiratory system and studies on laboratory animals and humans show that these pollutants irritate the lining of the lungs and cause respiratory stress (Coffin and Stokinger, 1976). Organisms are exposed to air pollutants enroute three pathways: (1) Inhalation of gases or small particles, (2) Ingestion of particles suspended in food or water and (3) absorption of gases through the skin. Organisms response to pollutants varies and depends on the type of pollutants involved, exposure time and volume of pollutants taken up by the animal. Organism's age, sex, health and reproductive condition also play a role in its response (Maniero, 1996). The most outstanding effect of air pollution resulting from flaring of crude oil associated gas and petroleum refining activities in the Niger-delta region of Nigeria is acid rain. Over 2.5 billion $\mathrm{Fe}^{3}$ of crude-associated gas is flared in Nigeria daily with an estimated yearly financial loss of $\$ 2.5$ billion. Acid rain pre-cursor gases $-\mathrm{NO}_{2}$ and $\mathrm{SO}_{2}$ are products of high temperature reactions and gas flaring in the study, area makes this possible, hence we have reported acid rain in our previous studies (Nduka et al 2008, Nduka and Orisakwe 2010). Acid precipitation can wear away the waxy protective coatings of leaves, damage them and reduce photosynthesis. Important cations such as $\mathrm{K}^{+}, \mathrm{Ca}^{2+}, \mathrm{mg}^{2+}$ and $\mathrm{Na}^{+}$, which are very important to the welfare of green plants and the aquatic ecosystem, are leached out and become unavailable to plants, also toxic cations such as $\mathrm{Pb}^{2+}, \mathrm{Cd}^{2+}, \mathrm{Hg}^{2+}$ are demobilized into the aquatic ecosystem where they bioconcentrate in lugworms, barnacles, algae and other planktonic and benthic organisms enroute to food webs. Sulphates and nitrates, which form in the atmosphere from sulphur dioxide $\left(\mathrm{SO}_{2}\right)$ and nitrogen oxide $\left(\mathrm{NO}_{2}\right)$ emissions, contribute to visibility impairment. The ubiquitous soot (black carbon) or Charcoal 
(Goldberg, 1985) which normally give rise to black rain in Niger-delta region of Nigeria is one of the major components of air pollution worldwide.

\section{Public health impact resulting from crude oil exploration and exploitation}

Apart from acidic precipitation and its negative impact, acid rain precursor gases $\left(\mathrm{NO}_{2}\right.$ and $\mathrm{SO}_{2}$ ) are part of six (6) common outdoor pollutants (ALA, 1996). Noise and thermal pollution from numerous gas flare points and extensive fire disasters that characterize the study area have led to extinction of some exotic species that are hunters delight. Inhalation of fine particulates that are fallouts from acid precursor gases have been linked to illness and premature death from heart and lung disorders such as asthma and bronchitis (USEPA, 2001). Nitrogen dioxide $\left(\mathrm{NO}_{2}\right)$ poses a health threat itself as well as playing a major role in the formation of the photochemical pollutant ozone. Previous studies has shown that animals exposed to $\mathrm{NO}_{2}$ have diminished resistance to both bacterial and viral infection (Gardner, 1984), while children exposed to high indoor levels of $\mathrm{NO}_{2}$ may become more susceptible to critical infections of the lower respiratory tract, bronchial tubes and lungs, and may develop bronchitis and chest cough with phlegm (Neas et al, 1991). Sulphur dioxide $\left(\mathrm{SO}_{2}\right)$ is a temporary irritant, though research have shown that increased levels of $\mathrm{SO}_{2}$ in conjunction with particulate matter may trigger small, but measurable, temporary deficits in lung function (Dockery et al, 1986). Epidemiological studies have found that the impact of $\mathrm{SO}_{2}$ is inseparable from that of particulate matter, but effects of the two classes of pollutants have been differentiated by an analysis exemplified by studies in Uta valley (Pope et al, 1992). The major health impact of $\mathrm{SO}_{2}$ is on population groups susceptible to pollutant effect due to pre-existing conditions, such as asthma. Measurable atmospheric levels of $\mathrm{SO}_{2}$ and $\mathrm{NO}_{2}$ exist in the Niger-delta region of Nigeria which gave rise to acidic precipitation we have reported in the region (Nduka and Orisakwe, 2010). In the area, serious health problems such as skin cancers and lesions may be linked to acid rain. Stomach ulcers could also occur, as consumption of acidic water can alter the $\mathrm{pH}$ of the stomach and leach the mucous membrane of the intestinal walls, this is more so as Nigerians depends heavily on rain water for drinking, cooking, laundry and other domestic uses.

Degradation processes such as photolysis, hydrolysis, oxidation and biodegradation are all involved in the chemical transformation of a compound upon its entry into the environment. The value of $C_{10}$ to $C_{3} \mathrm{O}$ straight chain hydrocarbon and the concentrations of chloride ion in the water samples of the Niger Delta region of Nigeria, shows that the formation of polychlorinated-n-alkanes (PCAs) of the general formular $\mathrm{C}_{n} \mathrm{H}_{2 n}{ }_{2}{ }_{2}-\mathrm{Cl}_{2}$ is possible (Nduka and Orisakwe, 2011). Polychlorinated-n-alkanes (PCAs) are normally manufactured in the presence of ultra violet (UV) light (Tony et al. 1998). The surface water of the region where crude oil spill occurs are wide open to direct ultra violet (UV) light from the sun, its formation is by simple substitution of hydrogen atoms by chlorine atoms, an example of chain reaction involving free radicals (Morrison and Boyo, 1983), also for the fact that the temperatures of water are above ambient values even in rainy season (Nduka and Orisakwe, 2011) shows that their formation is possible. Those of great interest are the $C_{10}-$ $\mathrm{C}_{13}$ PCAs, which have the greatest potential for environmental release (Environmental Canada 1993a) and the highest toxicity of PCA products (Serrone et al, 1987, Wills et al 1994, Mukherjee, 1990). Taken together, the carcinogenic effect of Polyaromatic hydrocarbons (PAHs) and the fact that study has shown that the $\mathrm{C}_{10}-\mathrm{C}_{13}$ PCAs inhibit intercellular communication in rat liver epithelial cells, a phenomenon that suggests these chemical may 
be acting as tumor promoters (Kato, 1996), could accelerate environmental and public health hazards such as malignant lymphomas (Omoti and Halim 2005, Omoti, 2006) and soft tissues sarcomas (Seleye-fubara et al, 2005) already reported in the Niger Delta region of Nigeria. In addition to these above, high nitrate levels in water samples from the region can also result in incidences of some cancers and lesions (Gulis et al, 2002), spontaneous abortion and ectopic pregnancy also reported in the area (Gbaforo and Igbafe, 2002). Pollution keratoconjuctivitis have been reported among children in oil-producing areas of Niger Delta, Nigeria. It has adverse consequences due to accumulation of differed categories of pollutants from drilling, production, refining of crude oil and production of petrochemicals, mainly black carbon. Persistent itching, foreign body sensation and specified areas of conjunctiva/limbal discoloration were used as markers for Pollution Kerato Conjunctivitis (PKC) (Asonye and Bellow, 2004). In their work investigation into the pharmacological basis for some of the folkloric uses of bonny light crude oil in Nigeria, Orisakwe et al, 2000, discovered that Nigerian bonny light crude oil caused complete inhibition of histamine-induced smooth muscle contraction while producing only a partial inhibition of the acetylcholine-induced contraction. It had no effects on the acetylcholineinduced skeletal muscle contraction, but proved good to analgesic effect that is comparable to aspirin. Because of complex composition of crude oil, it has multiple potential type of toxic effect which may include long term petroleum pollution on individual organism such as impaired reproduction (Feuston et al, 1997), reduced growth (Eisler, 1987), tumours and lesions (Malins and Ostrander, 1994), blood disorders (Yamato et al 1996) and morphological abnormalities (Kennish, 1997). Crude oil showed changes in the hypothalamo-pituitary-thyroid adrenal axis when male rats were exposed to it, and the effect is believed to be due to stress (Vyskocil et al, 1988). The Nigeria nation has an outrageous twelve million infertile people though not restricted to oil producing areas alone (Giwa-Osagie, 2003, whose infertility is believed to be due to infection (Cates et al, 1985), although some infection do persist after treatment. There are elevated consistence oligospermia or azoospermia in Nigeria than most other causes of infertility and less resources for its management (Osegbe and Amaku, 1985). Therefore it has been established that the Nigerian bonny light crude oil is a testicular toxicant and its use as a folklore medicine (which is very ubiquitous) in Nigeria may cause infertility (Orisakwe et al, 2004). They have also reported that the kidney cells of an adult albino rats were damaged by bonny light crude; crude oil caused a destruction of the renal reserve capacity (Orisakwe et al 2004).

\section{Conclusion}

Commercial exploration and exploitation of huge crude oil deposits and gas reserves in the Niger-Delta region of Nigeria has resulted in the alteration of the regions environment in certain negative manner. Vegetation is cleared to make way for seismic lines, roads are built, drilling mud and oil may reach surface water. The effect is the millions of barrels of crude oil and its lower fraction spills that results from various operations, damaging valuable commodities in the environment, plants and animals, harbours, beaches, marinas are devastated making them unfit for use. Due to its complicated composition, petroleum hydrocarbon has the potential to eliciting various toxic effects, which can cause acute lethal toxicity, sub lethal chronic toxicity or both depending on the exposure, dosage and type of organism exposed. Toxicity is not restricted to the immediate surrounding of the spill due to 
dispersion, dilution and deposition of oil into the water column and onto shores and sediments through various mechanisms, all organisms within the influence may be exposed to adverse effect associated with the oil. We can rightly conclude that crude oil exploitation in the Niger-Delta region of Nigeria is a major environmental and public health concern.

\section{References}

Achi SS and Shide EG (2004), Analysis of Trace Metals by Wet ashing and spectrophotometric Techniques of crude oil Samples. J. chem. Soc. Nigeria, 29 (11):11-14

Abam TKS, Okagbue PI (1997). The cone penetrometer and soil characterization in the deltas; Journal of Mining and Geology; 33(1): 15-24

Adeyemi O.T (2004), Oil exploration and environmental degradation. The Nigerian experience. Environ. Inform. Arch. 2: 387 - 393

Albers, P.H. (1995). Petroleum and individual polycyclic aromatic hydrocarbons in: Handbook of Ecotoxicology. Hoffman D.J, Rattner BA, Burton Jr. J.A, Cairns Jr J, eds. Lewis Publishers, Boca Raton, FL, 330 - 355

Amadi UMP, Amadi, PA (1990). Salt water migration in the coastal aguifers in the Nigeria; Journal of Mining and Geology; 26(1): 35

Amadi P.A (1986). Characteristics of some natural waters from the Port-Harcourt area of Rivers State, Nigeria. Unpublished MCG Thesis, University of Ibadan, 98

Amaize, E (2007), Crises from the Creeks. Saturday vanguard Newspapers (www.vangardngr.com). March 17. pp 11-13

American Lung Association (ALA.1996). Health Effects of outdoor Air Pollution. 13, 18-20

Anyakora C, Ogbeche A, Palmer P, Coker H (2005). Determination of Polynuclear aromatic hydrocarbons in marine samples of siokolo fishing settlement. J. of chromatography A; 1073: $323-330$

Anyakora C, Ogbeche A, Palmer P, Coker H, Ukpo G, Ogah C. (2005). GC/MS analysis of polynuclear aromatic hydrocarbons in sediments samples from Niger-Delta region. Chemosphere; 60: 990 - 997

Anyakora C, Coker H (2006). Determination of polynuclear aromatic hydrocarbons (PAHs) in selected water bodies in the Niger Delta. A.J. Biotechnologyl 5(21): 2024 - 2031

Anyakora CA, Ogbeche KA palmer P, Coker H, Ukpo G, Ogah C (2004). A screen for Benzo (a) pyrene a carcinogen, in the water samples from the Niger Delta region. Nigeria. J. Hosp. Med., 14: 288-293

Asonye C.C and Bello E.R (2004). The blight of pollution kerato conjunctivitis among children in oil - Producing industrial areas of Delta State, Nigeria. Ecotoxicology and Environmental safety. 59:244 - 248

Awosika LF (1995). Impacts of global climate change and sea level rise on coastal resources and Energy development in Nigeria. In: Umolu, J.C (ed). Global climate change: impact on Energy Development. DAMTECH Nigeria Limited Nigeria

Atlas RM (1991). Microbial hydrocarbon degradation: Bioremediation of oil spills. Biotechnology. 52:149-156

Atlas RM, and Bartha R (1973). Fate and effects of pollution in marine environment. Residues Review; 49: 49 - 85

Bowman J.A and Wills J.B (1967). Some application of the nitrous Exide-acetylene flame in chemicals analytical by atomic absorption spectrometry, Analytical chemistry, 39 (11); 1210 - 1216 
Baek SO, Field R.A, Gold Stone RA, Kirk. PW, Lester JN, Perry R, (1991). A review of atmospheric polycyclic hydrocarbons, sources, fate and behavior. Water, Air, Soil Pollut; 60: 279

Barwise I.G. (1990). Role of nickel and vanadium in petroleum classification. J. American Chem. Soc. $47-65$

BICNEWS (2005). Bioremediation: nature's way to a cleaner Environment. Malaysian Biotechnology information centre (MABIC). 9: 1-6 (www.bic.org.my)

Blokker PC (1964). Spreading and Evaporation of Products on water, $4^{\text {th }}$ International Harbour conference, Antwerp

Bob L. (1990). Waste and pollution Basi/Blackwell Ltd. 108 Cowley Road. Oxford, OX41JF, England. 40 - 51

Burwood R, and Speers G.C. (1974) Photo-oxidation as a factor in environmental dispersal of crude oil. Estuarine coastal Mar Sci; 2: 117 - 135

Cates W, Farley TMM. Rowe P.J (1985). Worldwide patterns o infertility, is Africa different? Lancet; 2:596 - 598

Clark R.B (1992). Marine pollution. Clarendon Press, Oxford

Coffin DL and Stokinger H.E (1976). Air Pollution, $3^{\text {rd }}$ ed. Vol. 11, A.C. Stern ed., Academic Press, New York. 231-360

Coon N.C and Dieter MP (1981), Responses of adult mallard ducks to ingested south Louisana crude oil. Environ. Res; 224: 309 -314

Cote, R.P (1976). The effects of Petroleum industry liquid wastes on aquatic life with special emphasis on the Canadian environment. National Research council Canada, Canada

Delaune R.D, Gambrell R.P, Pardue J.H, Patrick Jr. JH (1990). Fate of Petroleum Hydrocarbons and toxic organics in Louisana coastal environments, Estauries 13: 17 - 21

Dockery, D.W et al ( 1986). Change in pulmonary function in children association with air pollution episode. J. Air pollut. Control Assoc. 32:937-942

Eisler R. (1987). Polycyclic aromatic hydrocarbon hazard to fish, wild life and invertebrates: a synoptic review, vol. 85. Washington, Dc: fish and wild life service, US Department of interior, 1-11

Ekundayo EO, Obuekwe CO (2001). Effects of an oil spill on soil physico-chemical properties of a spill site in a typic udipsamment of the Niger Delta basin of Nigeria. Environmental Monitoring and Assessment; 60(2): 235-249

Ellrich J, Hirner A, Stark H (1985). Distribution of trace elements in crude oil from southern Germany, J.Chem. Geol. 48; 313 - 323

Environment Canada (1993a). Priority substances program. CEPA assessment report, chlorinated Parafins, commercial chemicals Branch, Hull, Quebec

Fay TAC (1969) The Spread of oil slick on a calm sea.Oil on the sea (D.P. Hoult, Ed), Plenum. $53-63$

Feuston MH, Hamilton CE, Schreiner CA, Mackerer CR (1997).Developmental toxicity of dermally applied crude oil in rats. J. Toxicol. Environment Health; 52; 79 - 93.

Fry DM. Swenson J, Addiego L.A, Grau CR, Kang A (1986). Reduced Reproduction of Wedge-tailed shearwaters Exposed to Weathered Santa Barbara Crude oil. Arch Environ. Contam. Toxicol. 15: 453 - 463

Gardner, D.E (1984). Oxidant- induced enhanced Sensitivity to infection in animal model and their extrapolation to man. J. Toxicol. Environ. Health 13,423-439 
Galt J.A, Lehr W.J, Payton D.L (1991). Fate and transport of the Exxon Valdez oil spill. Environ Sci Technol; 25: 202 - 205

Garner HF, Fellow OBE, Green SJ, Harper FD, Pegg RE (1953), J. Inst. Petroleum, 39: 279 293

Gharoro EP, Igbafe AA (2002). Ectopic Pregnancy revisited in Benin City, Nigeria: analysis of 152 cases. Acta Obstet Gynecol Sand; 81 (12): 1139-1143

Gbadebo, A.M, Taiwo, A.M and Ola OB (2009). Effects of crude oil and spent oil on clarias garipinus, a typical marine fish. American journal of Environmental Sciences; 5(6): 752 $-758$.

Giwa-Osagie O.O (2003). Nigeria has twelve million infertile persons Pharmanews; 25(7): 48 49

Goldberg E.D. (1985). Black Carbon in the Environment. Properties and Distribution. Wiley, New York

Gorsline J and Holmes WN (1981). Effects of petroleum and adreno-cortical activity and on hepatic naphthalene-metabolizing activity in mallard ducks. Arch. Environ contam Toxicol; 10: 765 - 777

Gulis G, Gomolyova M, Cerhan JR (2002). An ecologic study of nitrate in municipal drinking water and cancer incidence in Trnava District, Slovakia. Environ Res; 88: 182 -187

Gundlack E.R, Boehm P.D, Marchland M, Atlas R.M, Ward D.M, Wolfe D.A. (1983). The fate of Amoco cardiz oil. Sciences. 221: $122-129$

Hamlat, MS, Djeffal S and Kadi H (2001) Assessment of radiation Exposures from naturally occurring radioactive material in the oil and gas industry. Applied Radiation and Isotopes; (1):141-146

Handson W.E. (1994) Chemical Technology of Petroleum, McGraw-Hill Books companyLondon. 141 - 162

Hettinger (Jr) WR, Keith CD, Ging JL and Teter W (1955), Ind. Eng, Chem. 47 719-730

Holmes W.N, Cavanaugh K.P, Cronshaw J. (1978). The effects of ingested petroleum on oviposition and some aspects of reproduction in experimental colonies of Mallard ducks (Anas platyrhynchos). J. Reprod. Fert; 54; 335 - 347

Huang CP and Elliot H.A. (1977). The stability of emulsified crude oils as affected by suspended particles in: fates and effects of petroleum and hydrocarbons in marine organisms and Ecosystem. Wolfe D.A, ed. Pergamon Press, New York. 413 - 420

Ibru, G (2001), Hotel and tourism development Potentials in Delta State, A paper presented at the $2^{\text {nd }}$ anniversary of the administration of James Onanefe Ibori, Executive governor of Delta State at the conference hall; Hotel excel, NNPC Road, Effurun, Nigeria, June and 2001

Ideriah TJK and Stanley H.O (2008). Air quality around some cement industries in Port Harcourt, Nigeria. Scientia Africana 7(2): 27 -34

Jeffrey, P.G (1973). Large scale Experiments on spreading of Oil at sea and its Disappearance by natural factors. In conference on prevention and control of oil spills. API and EPA, Washington, 469

Jibiri N.N, Emelue HU (2008). Soil radionuclide concentrations and radiological assessment in and around a refining and petrochemical company in Warri, Niger Delta, Nigeria. J. Radiol. Prot. 28(3): 361 - 368

Karchmer JH and Gunn EL (1952), Determination of Trace metals in petroleum fractions, Analytical chemistry, 24(11); 1733 - 1734 
Kawchan J.A (1955), Quantitative spectrographic determination of vanadium in petroleum products by logarithmic rector method, Analytical Chemistry, 27 (12): 1873-1874.

Kennish MJ (1997). Practical handbook of estuarine and marine pollution Boca Raton, FL: CRC Press: 83 - 95

Lambert-Aikhionbare DO, Bush PR, Ibe AC (1990). Integrated geological and geochemical interpretation of source rock studies in the Niger Delta. Journal of Mining and Geology; 26(1): 97-106

Lewis FH and Sani M (1981), from Hydrocarbons to Petrochemicals, 1st ed, Gulf Publishing, Saudi Arabia, 38-47

Lorber M, Cleverly D, Sehuam J, Philips L, Schweer G, Leighton T (1994). Environ Sci. Technoil. 156:39

Mackay D. and McAuliffe C.D (1989). Fate of hydrocarbons discharged at sea. Oil chem. Pollut; 5: 1 - 20

Malins DC and Ostrander GK (1994). Aquatic toxicology. Molecular, biochemical, and Cellular perspectives. Chelsea, MI: Lewis Publishers

Manahan SE (1979). Environmental Chemistry, 3rd edition; Willard Grant Press, Boston, Massachusetts 331-398

Maniero T.G. (1996). The effect of Air Pollutions on Wild life and implication in class I Areas. National Park Service Air Resources, Denver, Colorado. 1-9

Milner O.I (1963), Analysis of Petroleum for Trace Metals, International series of monographs on analytical chemistry Pergamon press, oxford, England 1435 - 81

Ming ET and Both LL (1956), Petroleum Refiner, 35 192-194

Morrison RT, Boyd RN (1983). Organic chemistry, $4^{\text {th }}$ ed. Allyn and Bacon. Newton, MA

Mukherjee AB (1990). The use of chlorinated paraffins and their possible effects in the environment. National board of waters and the environment, Helsink, Finland. Series A66. National Board of waters and the environment, Helsinki, Finland

National Atlas (1987). Atlas of the Federal Republic of Nigeria. Lagos Government press, 136.

National Research Council (1985). Oil in the sea: imputs, fates, and effects. National Academy Press, Washington, D.C, 601

Nduka JKC, Orisakwe O.E. (2007). Heavy metal levels and physic-chemical quality of potable water supply in Warri Nigeria. Nigeria. Annali di chemica; 97 (9): 867 - 874

Nduka J.K and Orisakwe O.E (2011).Assessment of pollution profile of selected surface water in the Niger Delta region of Nigeria. Lambert Academic publishers, Germany

Nduka J.K, and Orisakwe O.E (2010) Precipitation chemistry and occurrence of acid rain over the oil-producing Niger Delta Region of Nigeria. The scientific world journal 10: $528-534$

Nduka JKC, Orisakwe O.E, Ezenweke L.O. (2010). Nitrate and Nitrite levels of potable water supply in Warri Nigeria: A public Health concern. J. Environ Health. 72 (6): 28 - 31

Nduka JKC, Orisakwe OE, Ezenweke LO, Ezenwa TE, Chendo MN, Ezeabasili N.G (2008), Acid Rain Phenomenon in Niger Delta Region of Nigeria: Economic, Biodiversity and Public Health Concern. The Scientific World Journal; 8: 811 - 818

Neas L.M, Dockery, D.W, et al (1991). Association of indoor nitrogen dioxide with respiratory symptoms and pulmonary function in children. American $J$. Epidemiology; 134: 204-209 
Neff J.M. (1987). Biological effects of oil in the marine environment. Chem Eng Progr; 83: 27 33

Neilson AH (1994). Organic chemicals in the Aquatic Envrionment: Distribution, persistence and Toxicity. Lewis, Boca Raton, FL

Neumann H.J, Lahme B, Severein D (1981). Geology of Petroleum: Composition and properties of petroleum. Vol 5, Halstead Press, New York, 131

Nieva - Cano M.J, Rubio-Barroso S, Santos-Delgado MJ (2001). Determination of PAH in food samples by HPLC with flourimetric detection following sonication extraction without sample clean-up. The Analyst. 126; 1326 - 1331

Nitrates in surface water. Ohio state University Extension, Department of Horticulture and crop Science 2021 Coffey Road, Columbus Ohio 43210-1044. AGF-204-95. http:/ / ohioline.osu.edu/agf-fact/0204.html (assessed March 26, 2008)

Nwaichi E.O. and Uzazobona M.A. (2011). Estimation of the $\mathrm{CO}_{2}$ level due to gas flaring in the Niger-Delta. Research journal of Environmental Sciences 5(6): 565 - 572.

Nwachukwu SCU (2000): J. Environ. Biol. 21, 241

Nwachukwu SCU, James P. Gurney TR (2001). J. Environ. Biol. 22:29.

Nwandinigwe C.A, Nworgu O.N (1999). Metal contamination in some Nigeria well heads Crudes. Comparative Analysis. J. Chem. Soc. Nigeria; 24:118 - 121

Okoro D, Ikolo A.O (2005). Compositional patterns and sources of polynulear Aromatic hydrocarbon in water and sediment samples of Ogunu creek of the Warri River. Proc. 28th Annual Int. Conf. Chem.. Soc. Nigeria. 2(1): 168-171

Olajire AA, Altenburger R, Kuster E, Brack W (2005). Chemical and ecotoxixological Assessment of polycyclic aromatic hydrocarbon-contaminated sediments of the Niger Delta, Southern Nigeria Science Total Environment. 340 (1-3): 123-136

Omati CE, Halim NK (2005). Adult lymphomas in Edo State, Niger Delta region of NigeriaUinicopathological profile of 205 cases. Clin lab Haematol; 27(5): 302-306

Omati CE (2006). Socio-demographic factors of adult malignant lymphomans in Benin City, Nigeria, Niger Postgrad Med. J; 13(3): 256-260

Orisakwe O.E, Akumaka DD, Njan A.A and O.J Afome (2004). Testicular toxicity of Nigerian bonny light crude oil in male albino rats. Reproductive Toxicology; 18: 439_ 442

Orisakwe O.E, Njan A.A, Afonne O.J, Akumka DD, Orish VN and Udemezue OO (2004). Investigation into the Nephrotoxicity of Nigerian Bonny light crude oil in Albino rats. Int. J. Environ. Res. Public Health: 1 (2); 106 - 110

Osagbe D.N and Amaku E.O. (1985). The causes of male infertility in 504 consecutive Nigerian patients. Int. Urol Nephrol; 17:349

Oteze GE (1983). Ground water levels and Ground movement. In S.A Ola (ed). Tropical soils of Nigeria in Engineering practice, Rotterdam: A.A. Balkema publishers, 172-195

Payne JR and Philips CR (1985). Petroleum spills in the marine Environment: the chemistry and formation of water-in-oil emulsions and Tar Balls. Lewis Publishers, Inc. Chelsea, MI

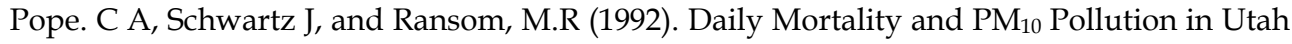
Valley. Arch. Environ. Health. 47, 211-217

Reijers TJA, Petters SW, Nwajide CS (1996); The Niger Delta Basin. In Selected chapters on Geology, Sedimentary Geology and Stratigraphy in Nigeria. SPDC, Nigeria. 103117 
Rosenberg E (1993). Microorganisms to combat pollution. Kluwer Academic publishers; Boston, USA

Seleye-fubara D, Nwosu S.O, Yellowe BE (2005) Soft Tissue sarcomas in the Niger Delta Region of Nigeria (a referral hospital study). Niger. J. med. 14(2): 188 - 194.

Serrone DM, Birtley RDN, Weigand W, Millisiher R (1987). Toxicology of chlorinated paraffins. Food Chem. Toxicol 25: 553-562

Shell Petroleum Development Company (SPDC), Nigeria (1997). Oil/chemical spill contingency plan and procedures Bulletin

Speight .J. (1999). The Chemistry and Technology of Petroleum. Marcel Dekker.

Teal JM (1993). A local oil spill revisited. Oceanus: 36: 65 - 70

Tiratsoo .E.N (1973). Oil fields of the word, Scientific press Ltd, England, 1- 68

Tony GT, Fisk AT, Westmore JB, Muir DCG (1998). Environmental chemistry and Toxicology of polychlorinated n-Alkanes. Rev Environ Contam Toxicol; 158: 53-128

USDHHS and ATSDR, (1995), U.S. Department of Health and Human Services and Agency for Toxic substances and diseases Registry (ATSDR), Toxicological profile for polycyclic Aromatic Hydrocarbons. August, 1995. ATSDR; Atlanta

U.S. Environmental Protection, Agency, clean Air markets Division, Acid Rain Programmers -2001 progress Report. EPA-430-R-02-009

Vyskocil A, Tusi M, and Obstril J. (1988) A subchronic inhalation study with unleaded petrol in rats. J. Appl Toxicol: 8: 239 - 242

Williams FB and Robert FD (1967), Petroleum Processing Hand book, McGraw -Hill, New York, $11-19$

Wills B, Crookes MJ, Diment J, Dobson SD (1994). Environmental hazard assessment: chlorinated paraffins. Toxic substances Division, Dept. of the Environment Garston, UK

Wilson VS, and LaBlanc GA (1999/2000). Petroleum Pollution. Rev Toxicol. 3: 77 - 112.

Yamato O, Goto I, and Maede Y (1996). Hemolytic anemia in wild seaducks caused by marine oil pollution. J. Wildlife Dis; 32: 381 -384

Young LY, Cerninglia CE (1995) Microbial Transformation and Degradation of Toxic Organic Chemicals, Wiley, New York 


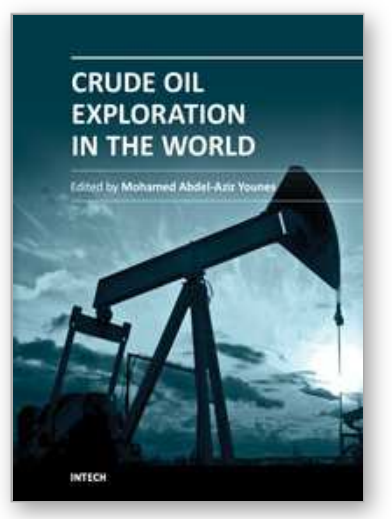

\section{Crude Oil Exploration in the World}

Edited by Prof. Mohamed Younes

ISBN 978-953-51-0379-0

Hard cover, 220 pages

Publisher InTech

Published online 16, March, 2012

Published in print edition March, 2012

"Crude Oil Exploration in the World" contains multidisciplinary chapters in the fields of prospection and exploration of crude oils all over the world in addition to environmental impact assessments, oil spills and marketing of crude oils.

\section{How to reference}

In order to correctly reference this scholarly work, feel free to copy and paste the following:

John Kanayochukwu Nduka, Fabian Onyeka Obumselu and Ngozi Lilian Umedum (2012). Crude Oil and Fractional Spillages Resulting from Exploration and Exploitation in Niger-Delta Region of Nigeria: A Review About the Environmental and Public Health Impact, Crude Oil Exploration in the World, Prof. Mohamed Younes (Ed.), ISBN: 978-953-51-0379-0, InTech, Available from: http://www.intechopen.com/books/crude-oilexploration-in-the-world/enviromental-impact-of-crude-oil-exloration-and-in-niger-delta-region-of-nigeria-areview

\section{INTECH}

open science | open minds

\section{InTech Europe}

University Campus STeP Ri

Slavka Krautzeka 83/A

51000 Rijeka, Croatia

Phone: +385 (51) 770447

Fax: +385 (51) 686166

www.intechopen.com

\section{InTech China}

Unit 405, Office Block, Hotel Equatorial Shanghai

No.65, Yan An Road (West), Shanghai, 200040, China 中国上海市延安西路65号上海国际贵都大饭店办公楼 405 单元 Phone: +86-21-62489820

Fax: $+86-21-62489821$ 
(C) 2012 The Author(s). Licensee IntechOpen. This is an open access article distributed under the terms of the Creative Commons Attribution 3.0 License, which permits unrestricted use, distribution, and reproduction in any medium, provided the original work is properly cited. 